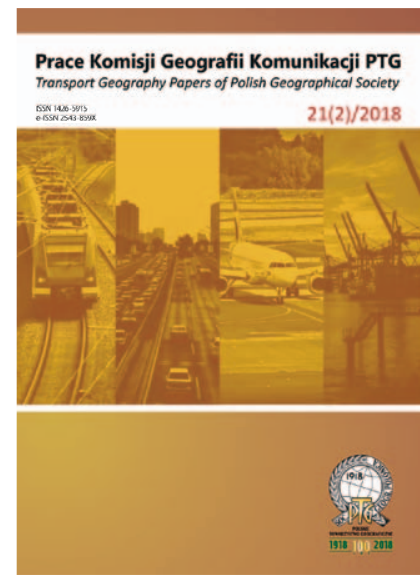

\title{
Prace Komisji Geografii Komunikacji PTG
}

2018, 21(2), 17-32

DOI 10.4467/2543859XPKG.18.007.9350

\section{ZRÓŻNICOWANIE PRZESTRZENNE SIECI TRAMWAJOWEJ KONURBACJ KATOWICKIEJ NA TLE ZAGOSPODAROWANIA PRZESTRZENNEGO}

\section{Spatial diversification of the tram network of the Katowice conurbation against the background of spatial development}

\author{
Krzysztof Mazur \\ Instytut Geografii i Gospodarki Przestrzennej, Uniwersytet Jagielloński, Gronostajowa 7, 30-387 Kraków \\ e-mail:k.mazur@mailmix.pl
}

\section{Cytacja:}

Mazur K., 2018,Zróżnicowanie przestrzenne sieci tramwajowej konurbacji katowickiej na tle zagospodarowania przestrzennego, Prace Komisji Geografii Komunikacji PTG, 21(2), 17-32.

Streszczenie: Przedmiotem badań jest sieć tramwajowa konurbacji katowickiej. Konurbacja ta to duży policentryczny region, w którym warunki funkcjonowania komunikacji są odmienne niż w ośrodkach monocentrycznych. W artykule przyjęto założenie, że jeżeli układ przestrzenny obszaru miejskiego obsługiwanego przez sieć tramwajową jest policentryczny, to policentryczna jest też struktura sieci tramwajowej. Postawiono hipotezę, że w obrębie sieci istnieje kilka mniejszych podsieci. Predysponowane są one głównie do realizacji lokalnych potrzeb przewozowych. Skutkiem tego jest niewielki wpływ komunikacji tramwajowej na integrację pomiędzy poszczególnymi częściami konurbacji. W oparciu o czynniki historyczne i własności topologiczne sieci dokonano jej podziału na mniejsze podsieci. Zbadano zróżnicowanie podsieci pod względem infrastruktury. Dostępność do komunikacji tramwajowej zbadano z wykorzystaniem zobrazowania układu przestrzennego konurbacji bazującego na koncepcji płat-korytarz-macierz pochodzącej z ekologii krajobrazu. Wskazano obszary dobrze obsługiwane oraz wykluczone z obsługi. Przeanalizowano ofertę przewozową, zwłaszcza pod względem oferowanych połączeń pomiędzy kilkoma wydzielonymi podsieciami. Przeprowadzone badania potwierdziły hipotezę, ale wykazały, że rola komunikacji tramwajowej jest przestrzennie zróżnicowana. W niektórych jej częściach sieć dobrze integruje ważne części konurbacji, a w innych - występują tylko przewozy lokalne.

Słowa kluczowe: dostępność, komunikacja tramwajowa, konurbacja katowicka, transport publiczny, zagospodarowanie przestrzenne

Abstract: The subjects of the research is tram network in Katowice conurbation. This conurbation is a big polycentric region where condition of the tram transport operation is different than in big monocentric agglomeration. The article assumes if the spatial arrangement of the conurbation is polycentric, then polycentric is also a structure of tram network. It was hypothesized that in a tram network are several smaller subnetworks. They are mostly predisposed to the implementation of local transportation needs. Therefore, tram transport has only little impact in integration between parts of conurbation. Based on historical factors and topological properties of network it was divided to smaller subnets. Subnets differ in terms of infrastructure. Accessibility to tram service was examined using landscape ecology ideas - "patch-corridor-matrix." Areas well served and excluded from service were indicated. Analyzed was also arrangement of tram lines and frequence of courses - with emphasis on connections between another subnets. The hypothesis were confirmed, but the studies showed that the role of tramway communication is spatially diverse. Some parts of conurbation are well integrated and in another parts - trams realize only local journey.

Key words: accesibility, Katowice conurbation, public transport, spatial development, tram transport 


\section{Wstęp}

Rozwój sieci tramwajowej konurbacji katowickiej miał miejsce na skomplikowanym tle historycznym i przestrzennym (ryc. 1). Łączy ona obszary tworzące złożony, policentryczny układ konurbacji, podczas gdy większość sieci tramwajowych obsługuje pojedyncze miasta o bardziej zwartym układzie przestrzennym. W artykule przyjęto założenie, że skoro układ przestrzenny konurbacji jest układem policentrycznym, to znajduje to odbicie w kształcie i funkcjonowaniu sieci tramwajowej.

Celem artykułu jest przedstawienie specyfiki sieci tramwajowej konurbacji katowickiej, relacji przestrzennych tej sieci z zagospodarowaniem przestrzennym oraz próba określenie roli, jaką pełni transport tramwajowy w konurbacji.

Postawiono hipotezę, że sieć tramwajowa konurbacji katowickiej wykształciła w swoim obrębie kilka mniejszych podsystemów. Podsystemy te są predysponowane do zaspokajania lokalnych potrzeb przewozowych i w niewielkim stopniu wpływają na integrację całej konurbacji. Niedostateczne dopasowanie kształtu sieci i oferty przewozowej do układu przestrzennego konurbacji wpływa na obniżenie znaczenia tramwajów dla funkcjonowania tego obszaru.

Do określenia obszaru badań spośród wielu delimitacji konurbacji katowickiej wykorzystano strefę rdzeniową konurbacji według opartej na wskaźnikach charakteryzujących komunikację miejską delimitacji A. Soczówki (2012c). Tworzą ją miasta: Będzin, Bytom, Chorzów, Czeladź, Dąbrowa Górnicza, Gliwice, Katowice, Mysłowice, Piekary Śląskie, Ruda Śląska, Siemianowice Śląskie, Sosnowiec, Świętochłowice, Tychy, Wojkowice oraz Zabrze.

Badaniami objęto lata 2012 i 2013. W tym okresie rozpoczęła się realizacja projektu "Modernizacja infrastruktury tramwajowej i trolejbusowej w aglomeracji katowickiej". W jego efekcie, już po okresie objętym badaniami, na dwutorowe przebudowano połącznie Szopienice-Sosnowiec - na trasie linii 15 i krótki odcinek na Brynowie - na trasie linii 6 i 16, jako dwutorową odbudowano trasę z Łagiewnik do centrum Bytomia - na trasie linii 7. Poza działaniami modernizacyjnymi doszło także do likwidacji odcinka pomiędzy Rudą Południową a Bobrkiem - trasa linii 18.

\section{Przegląd literatury}

W literaturze zauważany jest podział sieci tramwajowej konurbacji katowickiej na dwa lub trzy mniejsze podsystemy. Najczęściej mówi się o podziale na dwa podsystemy - wschodni i zachodni (Diagnoza stanu..., 2007), część śląską i zagłębiowską (Soczówka, 2012b). Na istnienie trzech podsystemów - bytomskiego, katowickiego i dąbrowskiego - połączonych w niezbyt spójną całość zwraca uwagę A. Kołoś (2006). Istnienie strefy centralnej wraz z zachodnią i strefy wschodniej wskazuje się w dokumentach strategicznych (Operacyjny program..., 2006). Podziały na więcej niż dwa podsystemy są interesujące, gdyż zwracają uwagę na niejednolitość śląskiej części sieci.

Istnieją dwie, częściowo przeciwstawne, grupy opinii dotyczących znaczenia tramwajów dla konurbacji jako całości. Pierwsza wskazuje na słabe wykorzystanie tramwajów w przewozach międzymiastowych: „zmarnowano szansę budowy sieci tramwajów międzymiastowych" (Kołoś, 2006). Druga uznaje, że przy słabym dopasowaniu do potrzeb lokalnych w niektórych miastach ważną rolę tramwaje odgrywają w przewozach międzymiastowych, a „większość obsługiwanych relacji łączy w sobie funkcje komunikacji miejskiej i międzymiastowej" (Halor, 2012). Praca J. Halora (2012) jest kompleksowym opracowaniem podejmującym od strony ekonomicznej problem zasadności funkcjonowania komunikacji tramwajowej jako takiej w konurbacji katowickiej. Na postawie obliczonych wskaźników efektywności autor ten uznaje za korzystne utrzymanie większości linii jako efektywniejszych niż autobusowe. S. Dziadek (1995) uznaje, że komunikacja tramwajowa ma istotne znaczenie dla integracji między miastami i stanowi substytut nieistniejącego metra. Także zdaniem A. Soczówki (2012b) w konurbacji katowickiej w czasach historycznych wykształcił się międzymiastowy charakter połączeń tramwajowych.

Przy okazji badań o zbliżonej, ale odmiennej tematyce, A. Soczówka (2012c) zauważa, że najsilniejsze powiązania realizowane komunikacją miejską pomiędzy gminami, rozumiane jako liczba połączeń, oparte są w dużej mierze na trakcji tramwajowej. J. Petryszyn (1996) zwraca uwagę na znaczenie tramwajów jako elementu integracji transportowej Śląska i Zagłębia, jednak rola połączeń tramwajowych wzrasta tu jedynie z uwagi na niedobór jakichkolwiek połączeń pomiędzy tymi regionami.

Historia sieci tramwajowej konurbacji katowickiej została kompleksowo opisana w pracach K. Soidy (1998) oraz K. Soidy i in. (2010). Szczegółowych informacji o charakterze przestrzennym na temat kolejnych etapów rozwoju sieci dostarcza Schemat Rozwoju Komunikacji Tramwajowej (Wilczek, b.d.). Bardzo syntetycznie, w ujęciu geograficznym, historię tramwajów w konurbacji katowickiej ujął A. Soczówka (2012b).

Podejmowane były próby określenia warunków brzegowych, które powinny być spełnione dla uzyskania uzasadnienia ekonomicznego dla komunikacji 
tramwajowej. W. Loose (2001), na podstawie badań we Fryburgu, przyjmuje, że liczba mieszkańców w promieniu $400 \mathrm{~m}$ od przystanku tramwajowego na poziomie 3 tys. czyni go opłacalnym. Liczbę ludności można przeliczyć na liczbę mieszkań - potrzeba ich około 70 na hektar. Podejście takie uzasadnia badanie komunikacji tramwajowej w kontekście zagospodarowania przestrzennego. W warunkach konurbacji katowickiej minimalne potoki pasażerskie umożliwiające osiągnięcie zadowalającej efektywności ekonomicznej tramwaju wynoszą od 2 tys. do 10 tys. osób na dobę zależnie od parametrów trasy i częstotliwości kursowania linii (Halor, 2012).

Tematykę dostępności komunikacji tramwajowej w konurbacji katowickiej w odniesieniu do zagospodarowania przestrzennego podjął M. Rechłowicz (2010) pisząc o obsłudze zakładów przemysłowych w Sosnowcu. W odniesieniu do komunikacji miejskiej w całej konurbacji zagadnienie to badał A. Soczówka (2012a, 2012c).

\section{Metody badań}

Idea sposobu prezentacji układu przestrzennego konurbacji katowickiej czerpie z dorobku ekologii krajobrazu i opiera się na próbie jego przedstawienia w ujęciu modelu krajobrazowego płatów, korytarzy i macierzy (matryc), „Kompozycja płatów, korytarzy i matryc [...] jest główną determinantą potoków funkcjonalnych i migracyjnych poprzez krajobraz" (Forman, Gordon, 1995: za: Pietrzak, 2010). Można zatem przyjąć, że jest też determinantą popytu i potoków pasażerskich dla sieci tramwajowej stanowiącej tu rodzaj korytarzy migracyjnych. Obraz płatów i macierzy w cytowanym opracowaniu uzyskany został na podstawie danych Urban Atlas (2006). Wykorzystane przedstawienie układu przestrzennego konurbacji składa się z płatów, które sklasyfikowano według wielkości i subpłatów będących wynikiem podziałów większych płatów.

W oparciu o dane OpenStreetMap i mapy archiwalne - niemiecką Mestichblatt w skali 1:50 000 oraz polską Mapę Taktyczną WIG w skali 1:100 000 w oprogramowaniu QGIS przygotowano bazę danych na temat infrastruktury tramwajowej i przebiegu dawnych granic państwowych. Zinwentaryzowano trasy - w podziale na jedno i dwutorowe. Uwzględniono też nieczynną w tym czasie trasę Bytom - Łagiewniki (traktowaną jako jednotorową). Oprogramowanie QGIS posłużyło również do wyznaczenia zasięgu oddziaływania przystanków za pomocą buforów ograniczonych stosowną ekwidystantą, a także do wykonania wszystkich pomiarów.

Do opisu kształtu sieci wykorzystano teorię grafów. W koncepcji płat-korytarz-macierz wykorzystu- je się ją do oceny połączeń pomiędzy płatami (Richling, Solon, 2011). Siecią połączeń między płatami jest tutaj sieć tramwajowa konurbacji katowickiej. Podstawowe pojęcia i metody teorii grafów stosowane w geografii transportu scharakteryzowali M. Potrykowski i Z. Taylor (1982). Wykorzystano także pojęcie zbioru rozspajającego zawierającego krawędzie, których usunięcie uczyni graf niespójnym (Wilson, 1985). W grafie sieci tramwajowej określono dostępność topologiczną wierzchołków. Dla każdego wierzchołka obliczono liczbę asocjacji oraz względną dostępność topologiczną - wskaźnik Stutza. Wierzchołki sklasyfikowano według liczby asocjacji w cztery klasy z podziałem dokonanym na podstawie średniej i odchylenia standardowego. Klasyfikację przedstawiono na rysunku grafu. Oznaczono na nim także wierzchołki centralne określone przez wskaźnik Stutza.

Dzieląc sieć na podsieci czynnik historyczny uwzględniono rozdzielając ją w miejscach przecięcia tras przez dawne granice państw. Brane pod uwagę cechy kształtu sieci to obecność krawędzi należących do zbioru rozspajającego, a także widoczne zróżnicowanie topologii na rysunku grafu, w tym obecność w niektórych jego częściach zwiększonej liczby cykli. Istotne jest, że nie dokonywano podziału grafu sieci, a samej sieci. W nowo utworzonych grafach poszczególnych podsieci dla wierzchołków reprezentujących te same miejsca w przestrzeni zastosowano nazwy analogiczne jak w grafie całej sieci.

Dokonano pomiarów długości tras, odcinków jedno- i dwutorowych. Obliczono ich procentowe udziały w całej sieci i w podsieciach. Za pomocą wskaźnika specjalizacji lokalnej Florence’a określono, które z nich w danej podsieci mają większe znaczenie. Wskaźnik ten oblicza się jako stosunek udziału procentowego danej cechy dla danej jednostki niższego rzędu do udziału procentowego tej cechy w jednostce rzędu wyższego. Najwyższa wartość ilorazu wskazuje na cechę najistotniejszą w danej jednostce (Runge, 1992). W artykule uwzględniono dwie cechy dla każdej podsieci: długość odcinków jednotorowych i dwutorowych. Za jednostkę wyższego rzędu przyjęto całą badaną sieć.

Dla analizy oferty przewozowej tramwajów przygotowano model przebiegu linii komunikacyjnych i częstotliwości kursów. Model ten nie odzwierciedla stanu na konkretny dzień, a przedstawia ogólne tendencje panujące przy kształtowaniu oferty połączeń tramwajowych. Uwzględnia przebieg linii kursującyh po stałych trasach w dłuższym okresie czasu, ale także linie-efemerydy o niskich częstotliwościach i krótkim czasie funkcjonowania. Podejście takie jest konieczne ze względu na nadmiernie częste zmiany rozkładów jazdy i tras linii. Jackiewicz i in. (2010) dla lat 2000-2009 odnotował aż 458 zmian. Do roku 
2013 trend w postaci niestabilności oferty przewozowej utrzymał się. Dodatkowo nałożyły się na niego utrudnienia związane z rozpoczęciem projektu "Modernizacja infrastruktury tramwajowej i trolejbusowej w aglomeracji katowickiej". Uwzględniono ofertę dostępną w dni robocze w godzinach 6:00-18:00. Model przedstawiono na schemacie i zestawiono go z mapą przedstawiającą układ przestrzenny konurbacji w postaci płatów.

Ostatnim etapem było zbadanie związków układu przestrzennego konurbacji katowickiej z siecią tramwajową. W tym celu przeanalizowano zróżnicowanie dostępności do sieci tramwajowej oraz związki pomiędzy rozmieszczeniem płatów a przebiegiem linii komunikacyjnych. Poziom dostępności do komunikacji tramwajowej określono w układzie subpłatów. Określając zasięg oddziaływania przystanków tramwajowych posłużono się modelem kół o wybranym promieniu. W Polsce zwyczajowo stosuje się promienie $500 \mathrm{~m} \mathrm{i} 1000 \mathrm{~m}$ (Beim, Majewski, 2008). Takimi też promieniami się posłużono. Nie jest to model doskonały. J. Gadziński (2010), A. Soczówka (2012c) zwracają uwagę, że zasięg przystanku mogą zmniejszyć różnego rodzaju bariery. Jednak w założonej skali analizy, tj. dla całej konurbacji, daje to wystarczająco dobry obraz dostępności. Dla każdego subpłata wyli- czono wskaźnik dostępności będący średnią ważoną jego powierzchni znajdującej się w zasięgach $500 \mathrm{~m}$ i $1000 \mathrm{~m}$. Wagi dla średniej ważonej dobrano arbitralnie. Zasięgowi $500 \mathrm{~m}$, jako zdecydowanie bardziej atrakcyjnemu, przypisano wagę 2, a akceptowalnemu zasięgowi $1000 \mathrm{~m}$ - wagę 1. Na postawie obliczonego syntetycznego wskaźnika dostępności określono ją kategoriami: bardzo dobra, dobra, dostateczna, słaba, bardzo słaba, brak dostępności. Kategorie te przypisano przedziałom wartości wskaźnika dostępności dobranym metodą tzw. naturalnego podziału.

\section{Podział sieci tramwajowej}

Sieć tramwajowa konurbacji katowickiej rozwijała się w specyficznych warunkach geopolitycznych. Obszar jej funkcjonowania dwukrotnie przecinany był granicami państw (ryc. 1). Tramwaj najwcześniej, bo jeszcze wXIX wieku, pojawił się na terenie należącym do Prus. W Zagłębiu komunikacja tramwajowa powstała dopiero w XX wieku, w okresie międzywojennym. Obszar ten należał już wówczas do Polski, a nie jak przed I wojną światową - do Rosji. W latach międzywojennych podziałowi pomiędzy dwa państwa - Polskę i Niemcy - uległa śląska część sieci.

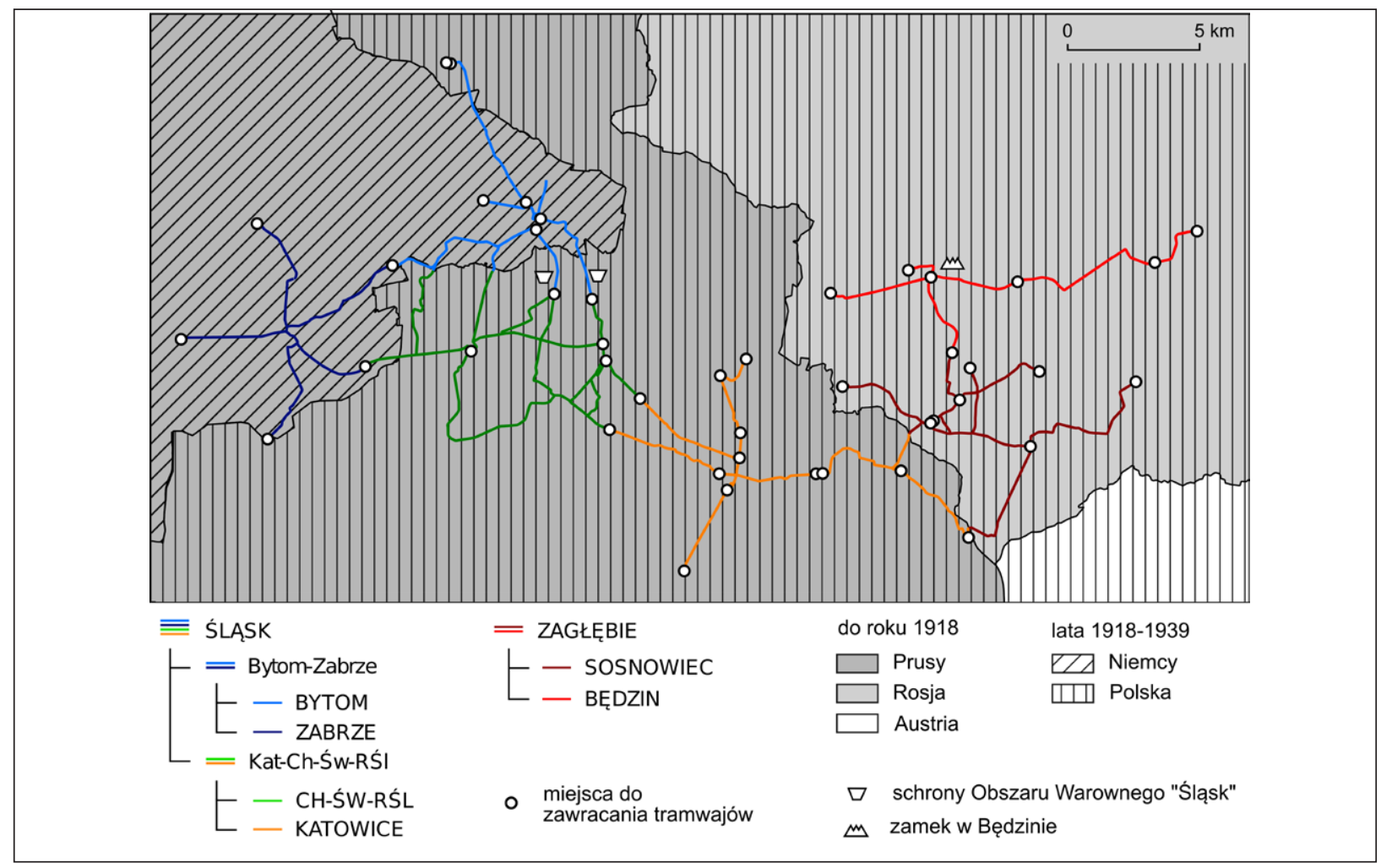

Ryc. 1. Podział sieci tramwajowej konurbacji katowickiej na podsieci na tle historycznych granic państwowych, stan sieci tramwajowej na grudzień $2012 \mathrm{r}$.

Źródło: opracowanie własne na podstawie Openstreetmap.org [25.05.2018], Mestichblatt w skali 1:50000 Mapy Taktycznej WIG w skali 1:100000. 
W całej sieci znaleziono 15-elementowy zbiór rozspajający. 12 usuniętych krawędzi powoduje powstanie grafów zerowych. Trzy krawędzie powodują rozpad grafu na izolowane podgrafy. Tylko dwa z tych podgrafów pozwalają wydzielić sensowne podsieci.

Na podstawie czynnika topologicznego i historycznego można wydzielić dwie duże podsieci "Śląsk" i „Zagłębie”. Najistotniejsza krawędź ze zbioru rozspajającego to Katowice-Szopienice $(25,29)$ (ryc. 2). Jej usunięcie powoduje rozdzielenie grafu na dwa duże podgrafy - dla Śląska i Zagłębia. Istnienie samotnej krawędzi $(25,29)$ pokazuje, że dawna granica prusko-rosyjska okazała się barierą niepokonaną do dnia dzisiejszego. Nie powstały alternatywne do reprezentowanego przez tę krawędź połączenia. Warto zaznaczyć, że trasa reprezentowana przez krawędź $(25,29)$ sama nigdy nie była przecięta granicą państwową. Ślad granicy przecięły dopiero później zbudowane trasy - krawędzie $(29,30)$ i $(29,37)$. Stąd fragmenty tych dwóch tras zostały zaliczone do podsieci śląskiej, zaś graf podsieci „Śląsk" na wschodzie ma postać rozwidlającego się drzewa, a nie pojedynczej krawędzi.

W podsieci "Śląsk" możliwy jest dalszy podział według czynnika historycznego. Dawna pruska część sieci została tu podzielona pomiędzy Polskę i Niemcy. Wymowną tego pamiątką są schrony Obszaru
Warownego "Śląsk” - polskich umocnień na granicy niemieckiej (ryc. 3). Granica ta nie znalazła odzwierciedlenia w topologii sieci. Przecięte zostały nią trasy reprezentowane przez krawędzie $(3,6),(2,7)$ - tu przebudowano trasę tak, by jej ślad ominął terytorium Polski, $(8,15),(9,17),(10,22)$. Odtwarzając przebieg granicy można wydzielić podsieci „Bytom-Zabrze” oraz "Katowice-Chorzów-Świętochłowice-Ruda Śląska” - dalej zwana "Kat-Ch-Św-RŚl” (ryc. 1).

Dalsze podziały możliwe są w oparciu o cechy topologiczne sieci. Można ich dokonać przede wszystkim znajdując elementy zbioru rozspajającego, niedające grafów zerowych w grafach wydzielonych podsieci (ryc. 4). W grafie podsieci "Bytom-Zabrze” istnieją dwa elementy zbioru rozspajającego niepowodujące powstania podgrafów zerowych. Ważna jest tu krawędź $(7,8)$. Jej usunięcie powoduje rozpad podsieci na dwa podgrafy. Jest to przesłanka do wydzielenia oddzielnych podsieci "Bytom" i "Zabrze” (ryc. 1, ryc. 4). Drugi element zbioru rozspajającego - krawędź $(10,13)$ - powoduje powstanie podgrafu zbyt małego, by w oparciu o niego wydzielić kolejną podsieć. W Zagłębiu ważnym elementem zbioru rozspajającego jest krawędź $(33,39)$. W oparciu o nią podzielono tę podsieć na dwie mniejsze - „Sosnowiec" $\mathrm{i}$ „Będzin”.

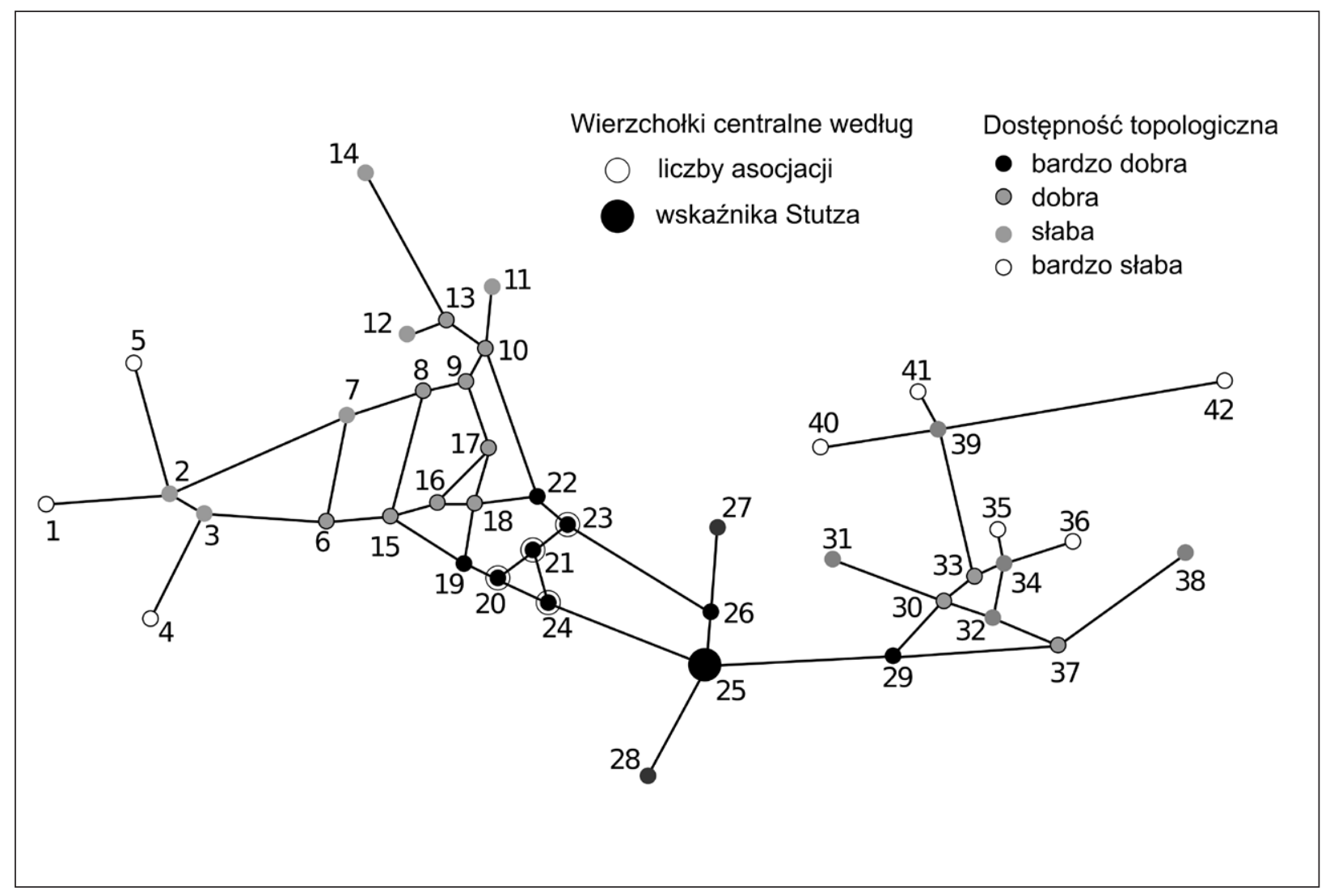

Ryc. 2. Graf sieci tramwajowej konurbacji katowickiej, wg stanu sieci na grudzień 2012 r.

Źródło: opracowanie własne. 


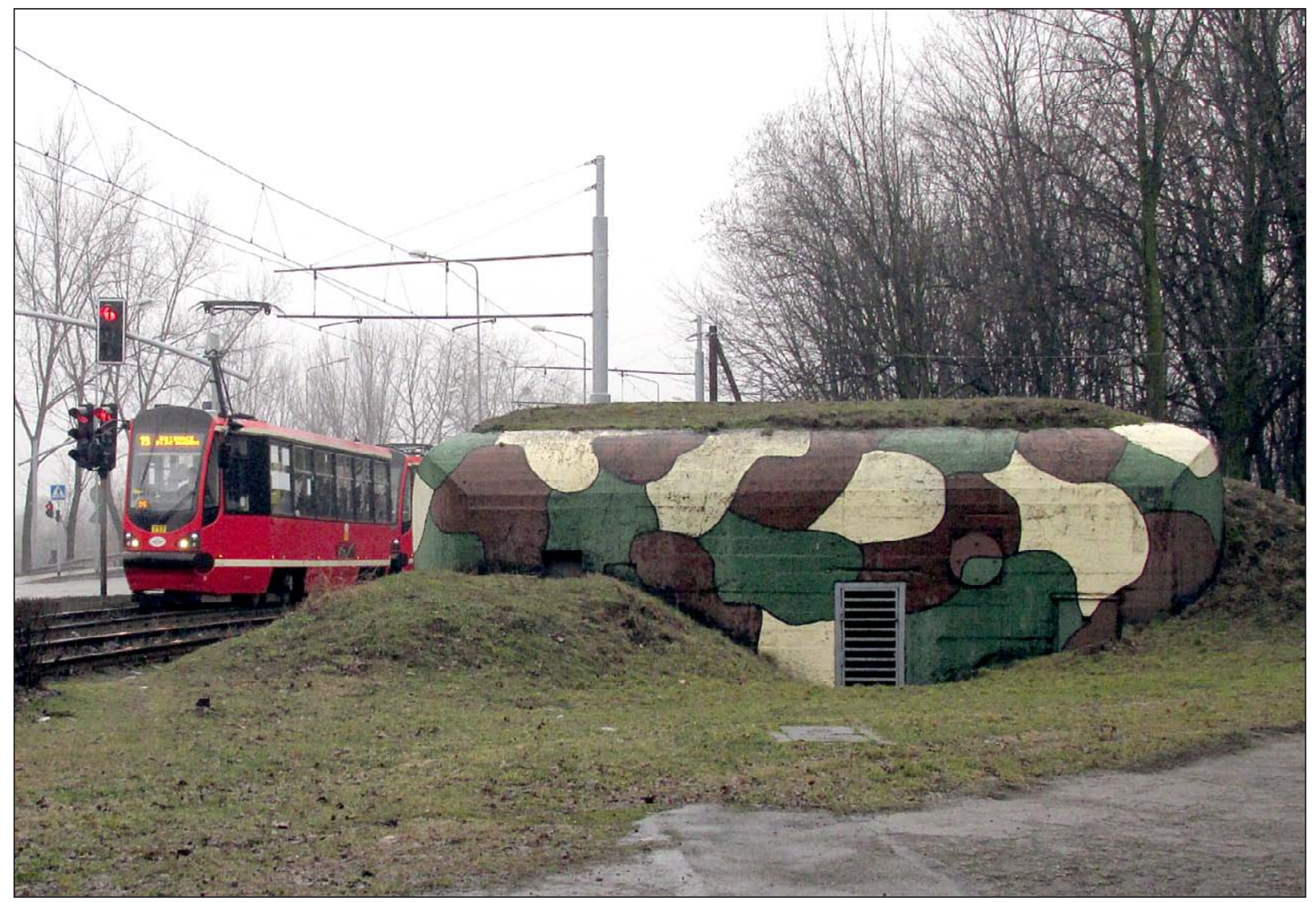

Ryc. 3. Schron Obszaru Warownego „Śląsk” przy trasie tramwajowej w Łagiewnikach.

Źródło: zbiory własne.

Podziału w oparciu o czynnik topologiczny można też dokonać analizując zróżnicowanie kształtu sieci. Podsieć „Kat-Ch-Św-RŚl” w części zachodniej jest znacznie bardziej złożona. W grafie występują tu liczniejsze cykle, choć niektóre z nich domykają się dopiero przez krawędzie (trasy) z podsieci „ZabrzeBytom". To zróżnicowanie kształtu sieci zdecydowało o jej podziale na zachodnią podsieć "Ch-Św-RŚl” o charakterze sieci kratowej i wschodnią "Katowice” o charakterze drzewa.

\section{Zróżnicowanie przestrzenne infrastruktury tramwajowej}

Duża liczba odcinków jednotorowych jest charakterystyczna dla sieci tramwajowej konurbacji katowickiej (Soczówka, 2012c). Długie odcinki o jednym torze ograniczają przepustowość trasy, determinują rozkład jazdy i wydłużony czas jazdy, wywołują uciążliwe postoje w oczekiwaniu na zwolnienie odcinka jednotorowego, opóźnienia wtórne, chaos komunikacyjny na danym fragmencie sieci (Molecki, 2007). Odcinki jednotorowe w sieci tramwajowej konurbacji katowickiej można podzielić na krótkie, średnie - wymagające uwzględnienia w rozkładzie jazdy, długie
- wymagające dopasowania czasów przejazdu do mijanek (Soczówka, 2012c).

Według wykonanych pomiarów odcinki dwutorowe w sieci tramwajowej konurbacji katowickiej mają sumaryczną długość $113 \mathrm{~km}$. W tej liczbie mieści się również 2,25 km przypadających na kryteria uliczne. Suma długości odcinków jednotorowych wynosi $60,5 \mathrm{~km}$. Zatem ponad 1/3 ogółu torowisk to odcinki jednotorowe (ryc. 5, tab. 1).

Podsieci różnicują się między sobą pod względem udziału i dominacji odcinków jednotorowych (tab. 1). W podziale na część śląską i zagłębiowską większym o niecałe $11 \%$ udziałem odcinków dwutorowych cechuje się Zagłębie. Także wskaźnik Florence'a każe uznać odcinki dwutorowe za bardziej charakterystyczne dla Zagłębia, a jednotorowe - dla Śląska. W mniejszych podsieciach udział odcinków jednotorowych waha się od $14,8 \%$ w podsieci będzińskiej do $38 \%$ w zabrzańskiej. Jedynie podsieć "Ch-ŚwRŚl" posiada ponad $50 \%$ odcinków jednotorowych. W świetle wysokiej wartości wskaźnika Florence'a dla nich wypada ona szczególnie niekorzystnie na tle reszty sieci. Natomiast wyraźna dominacja odcinków dwutorowych cechuje podsieci „Będzin”, „Bytom” i „Katowice”. 


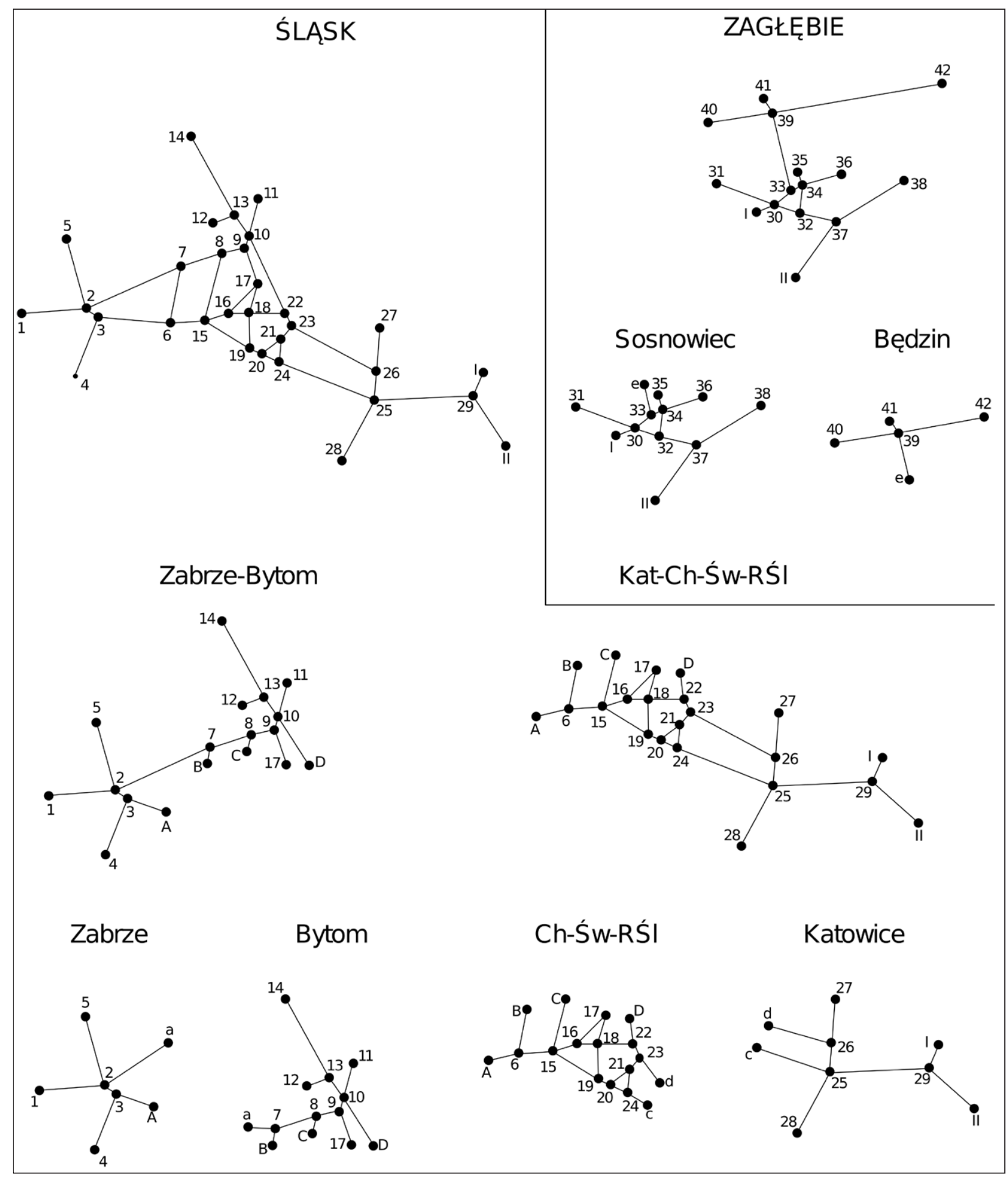

Ryc. 4. Grafy sieci tramwajowej i wyróżnionych w niej podsieci.

Źródło: opracowanie własne. 
Tab. 1. Udział torowisk pojedynczych i podwójnych.

\begin{tabular}{|l|r|r|r|c|}
\hline \multirow{2}{*}{ Sieć/Podsieć } & \multicolumn{2}{|c|}{ Udział procentowy } & \multicolumn{2}{c|}{ Wskaźnik Florence'a } \\
\cline { 2 - 5 } & $\mathbf{2}$ tory & $\mathbf{1}$ tor & $\mathbf{2}$ tory & $\mathbf{1}$ tor \\
\hline Będzin & 85,2 & 14,8 & 1,31 & 0,43 \\
\hline Bytom & 76,7 & 23,3 & 1,15 & 0,67 \\
\hline Katowice & 75 & 25 & 1,12 & 0,72 \\
\hline Zagłębie & 72,8 & 27,2 & - & 0,78 \\
\hline Cała sieć & 65,1 & 34,9 & 0,99 & 1,02 \\
\hline Sosnowiec & 64,5 & 35,5 & 0,95 & 1,09 \\
\hline Śląsk & 62 & 38 & 0,95 & 1,09 \\
\hline Zabrze & 62 & 38 & 0,67 & 1,62 \\
\hline Ch-Św-RŚl & 43,7 & 56,3 & & 15 \\
\hline
\end{tabular}

Ch-Św-RŚl - Chorzów-Świętochłowice-Ruda Śląska.

Źródło: opracowanie własne.

Rozmieszczenie miejsc (ryc. 5) do zawracania nawiązuje do przebiegu granic między poszczególnymi podsieciami oraz granic administracyjnych gmin. Po- zwala to na funkcjonowanie niektórych podsieci jako sieci mniejszych, całkowicie autonomicznych, w tym nawet wewnątrzmiejskich.

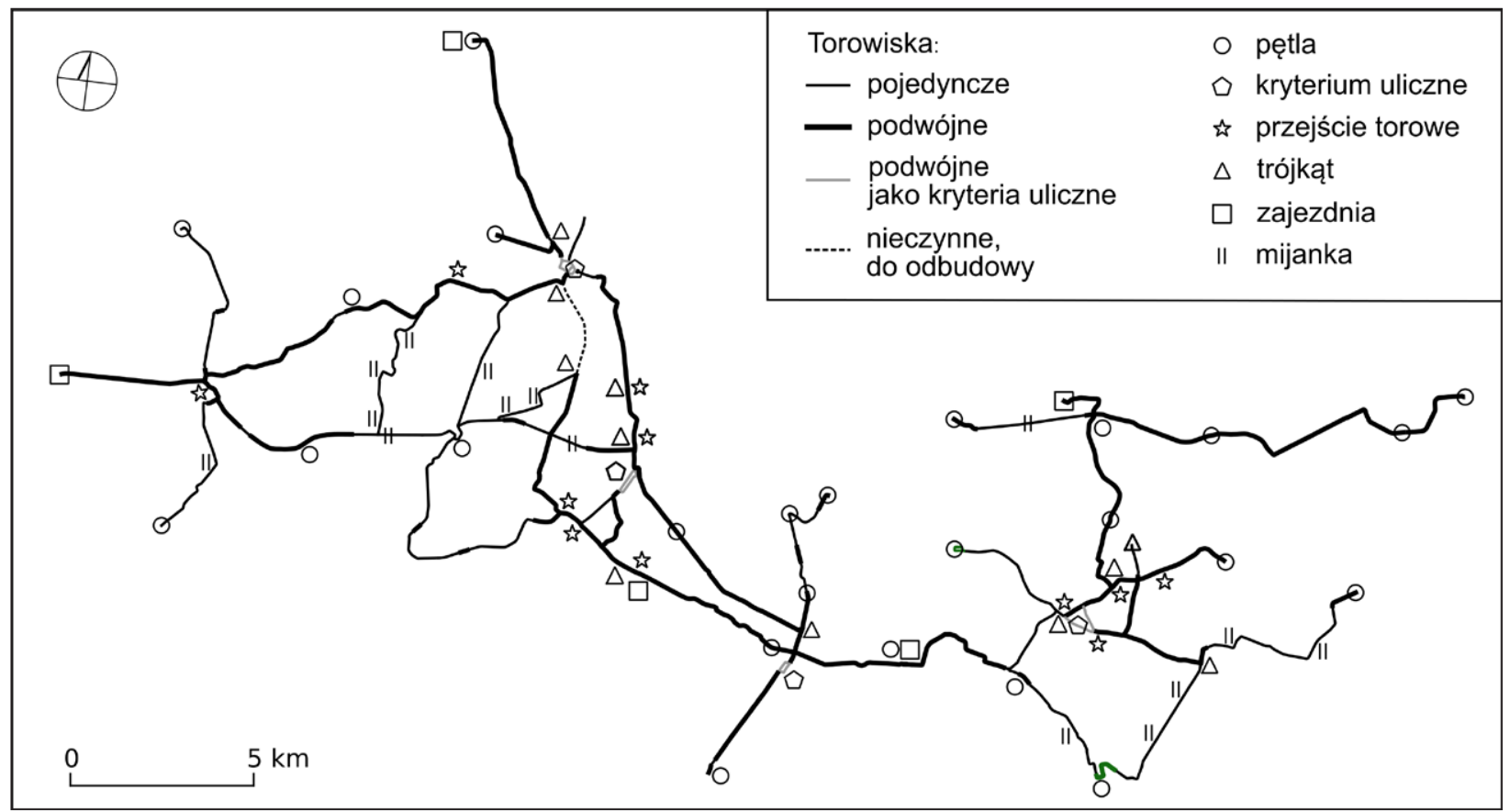

Ryc. 5. Infrastruktura tramwajowa konurbacji katowickiej, stan sieci tramwjaowej na grudzień 2012.

Źródło: opracowanie własne na podstawie OpenStreetMap [25.05.2018].

\section{Dostępność topologiczna i kształt sieci}

Średnica grafu, czyli najkrótsza droga między najbardziej oddalonymi wierzchołkami mierzona liczba krawędzi grafu, dla całej sieci wynosi 13, a najniższa liczba asocjacji to siedem. Najniższa liczba asocjacji cechuje cztery wierzchołki: 20 - Świętochłowice Gazownia, 21 - Chorzów Kościół św. Jadwigi, 23 - Chorzów Rynek, 24 - Chorzów Batory Dworzec PKP. Graf posiada zatem cztery wierzchołki centralne. Wszystkie znajdują się w podsieci „Kat-Ch-Św-RŚl”. W świetle wskaźnika Stutza wierzchołkiem centralnym jest wierzchołek 
stopnia czwartego leżący w środkowej części rysunku grafu całej sieci - 25 - Katowice Rynek. Wobec tego za najbardziej centralny przyjęto właśnie ten wierzchołek. Położenie wierzchołków centralnych wskazuje na przesunięcie ciężaru sieci bardziej ku jej części śląskiej (ryc. 2). Wierzchołek wybrany przez wskaźnik Stutza należy ponadto do jedynej krawędzi spajającej duże części grafu odpowiednie dla Śląska i Zagłębia. Potwierdza to znaczenie Katowic jako centralnego węzła sieci tramwajowej konurbacji.

Wierzchołki najlepiej dostępne koncentrują się w rejonie Katowic, Chorzowa i Świętochłowic. Jest to część sieci wyróżniona przy podziałach jako podsieć „Kat-Ch-Św-RŚI". Pośród tych wierzchołków znajdują się też wierzchołki centralne całej sieci. W tej części nie ma wierzchołków słabo i bardzo słabo dostępnych. Wierzchołki bardzo słabo dostępne występują w rejonie Zabrza, Będzina i w Sosnowcu (zasięg podsieci odpowiednio „Zabrze”, „Będzin” i „Sosnowiec”). Nie ma ich w okolicach Bytomia (podsieć „Bytom”). Biorąc pod uwagę dokonane podziały sieci, należy zatem stwierdzić, że pod względem topologicznym podsieć „Bytom” jest zdecydowanie lepiej zintegrowana z pozostałą częścią sieci niż inne podsieci.

Wyróżnione podsieci charakteryzują się różnym układem (ryc. 4). Podsieć „Bytom-Zabrze” jest typowym przykładem sieci rdzeniowej. W jej obrębie nie wytworzyły się żadne cykle. Rdzeniowe są też powstałe z jej podziału podsieci „Zabrze” i „Bytom”. Wiele cykli posiada podsieć "Kat-Ch-Św-RŚl”, szczególnie jej część „Ch-Św-RŚl”, a przez dołączenie krawędzi z sąsiednich podsieci możliwe byłoby utworzenie dalszych. Natomiast sama podsieć „Katowice” nie ma już cykli, jedyny możliwy powstaje przez dołączenie krawędzi z podsieci „Ch-Św-RŚI”. W podsieci "Ch-Św-RŚl” ujawniają się też cechy układu trójkątnego. Jednocześnie pomimo ułożenia torów w trójkąt, w związku z przyjętymi zasadami tworzenia grafu, cech sieci trójkątnej nie ma podsieć "Sosnowiec". Posiada ona tylko jeden cykl. Podsieć „Będzin” jest rdzeniowa. W podsieciach "Zabrze”, „Bytom”, „Katowice” i „Będzin” trasy gwiaździście zbiegają się do centralnie położonych punktów. Z wyjątkiem sieci będzińskiej można w nich utworzyć cykle przez dołączenie krawędzi z sąsiednich podsieci. W podsieci "Sosnowiec", a co za tym idzie w całej podsieci „Zagłębie", charakterystyczne jest gwiaździste zbieganie się wszystkich tras nie do jednego wierzchołka, ale do grupy wierzchołków tworzących jedyny cykl w tych sieciach $(30,32,33,34)$.

\section{Dostępność do sieci tramwajowej}

Jak zauważa A. Soczówka (2012c), jedynie w centrach kilku miast konurbacji katowickiej zasięgi dojścia pieszego, ustalone przez niego na 330 m, do przystanków komunikacji miejskiej - autobusowych, tramwajowych i trolejbusowych - łączą się w zwartą powierzchnię. W niniejszej pracy stwierdzono podobną prawidłowość dotyczącą zlewania się zasięgów przystanków w większe strefy z akceptowalnym dojściem, dotyczącą samych tramwajów. Strefa zasięgu 500 m, tworząca większą ciągłą powierzchnię, występuje tylko przy trzech z dziewięciu płatów bardzo dużych: w Chorzowie, Katowicach i Sosnowcu oraz przy jednym dużym w Bytomiu. W skład tych płatów wchodzą subpłaty o strukturze miejskiej, a cztery z tych subpłatów zawierają śródmieścia miast - Bytomia, Świętochłowic, Chorzowa i Katowic. Strefą tą objęty jest też jeden mały płat w Świętochłowicach obejmujący Lipiny, Chropaczów i Piaśniki (ryc. 6).

W Świętochłowicach, Chorzowie i Sosnowcu zwarte powierzchnie złożone ze stref oddziaływania kilku przystanków przy ekwidystancie 500 m powstają w miejscu występowania namiastki gęstszej sieci. W grafach tych części sieci widoczne są cykle. W Bytomiu jest to wynik zbiegania się tras z licznych kierunków do jednego punktu. Znaczenie dla rozciągnięcia strefy dostępności w zasięgu 500 m ma tu krótka linia nr 38. Duży obszar obsługiwany przez komunikację miejską w Katowicach to zasługa zbiegania się tras do jednego punktu oraz równoległego przebiegu dwóch tras w kierunku zachodnim. W Zabrzu i Będzinie zbieg kilku linii w punkcie nie powoduje już powstania wokół niego większej powierzchni z krótkim dojściem pieszym do przystanków. Strefa pozostałych obszarów z dostępem do przystanków tramwajowych w zasięgu 500 m jedynie naśladuje przebieg tras. Miejscami zostaje rozcięta tam, gdzie odległości międzyprzystankowe są większe. Jednak nie pogarsza to dostępności - przerwy występują w miejscach braku jakichkolwiek płatów, np. trasa Zabrze-Bytom.

Przy zasięgu 1000 m powstaje szeroka, przybierająca postać pasma, powierzchnia obsługiwana przez tramwaj ciągnąca się od Bytomia przez Chorzów i Świętochłowice do Katowic (ryc. 6). Jest to rejon całej podsieci „Kat-Ch-Św-RŚI” oraz centralnej części podsieci bytomskiej. Powierzchnią tą objęte są śródmieścia czterech miast i tereny pomiędzy nimi. Dopiero po przyjęciu zasięgu 1000 m większa ciągła powierzchnia obsługiwana przez tramwaj pojawia się w Zabrzu. Większa strefa wyznaczona ekwidystantą 1000 m w Zagłębiu występuje tylko w Sosnowcu.

Największe ciągłe powierzchnie z zapewnioną dostępnością do tramwajów występują w środkowej części konurbacji, rozciągając się nieco na północ. Przekraczają dawną granicę polsko-niemiecką, ale nie przekraczają granicy prusko-rosyjskiej. 
W wyniku analizy wartości obliczonego syntetycznego wskaźnika dostępności spośród 275 subpłatów, należących do 222 płatów różnych kategorii wielkościowych, za posiadające dostęp do komunikacji tramwajowej należy uznać 109 . Są to subpłaty o wskaźniku dostępności wyższym niż 9\%. Należą one do 68 różnej wielkości płatów. W zasięgu oddziaływania przystanków tramwajowych znalazły się subpłaty wszystkich rodzajów struktur użytkowania terenu i należące do płatów wszystkich kategorii wielkościowych (ryc. 6).

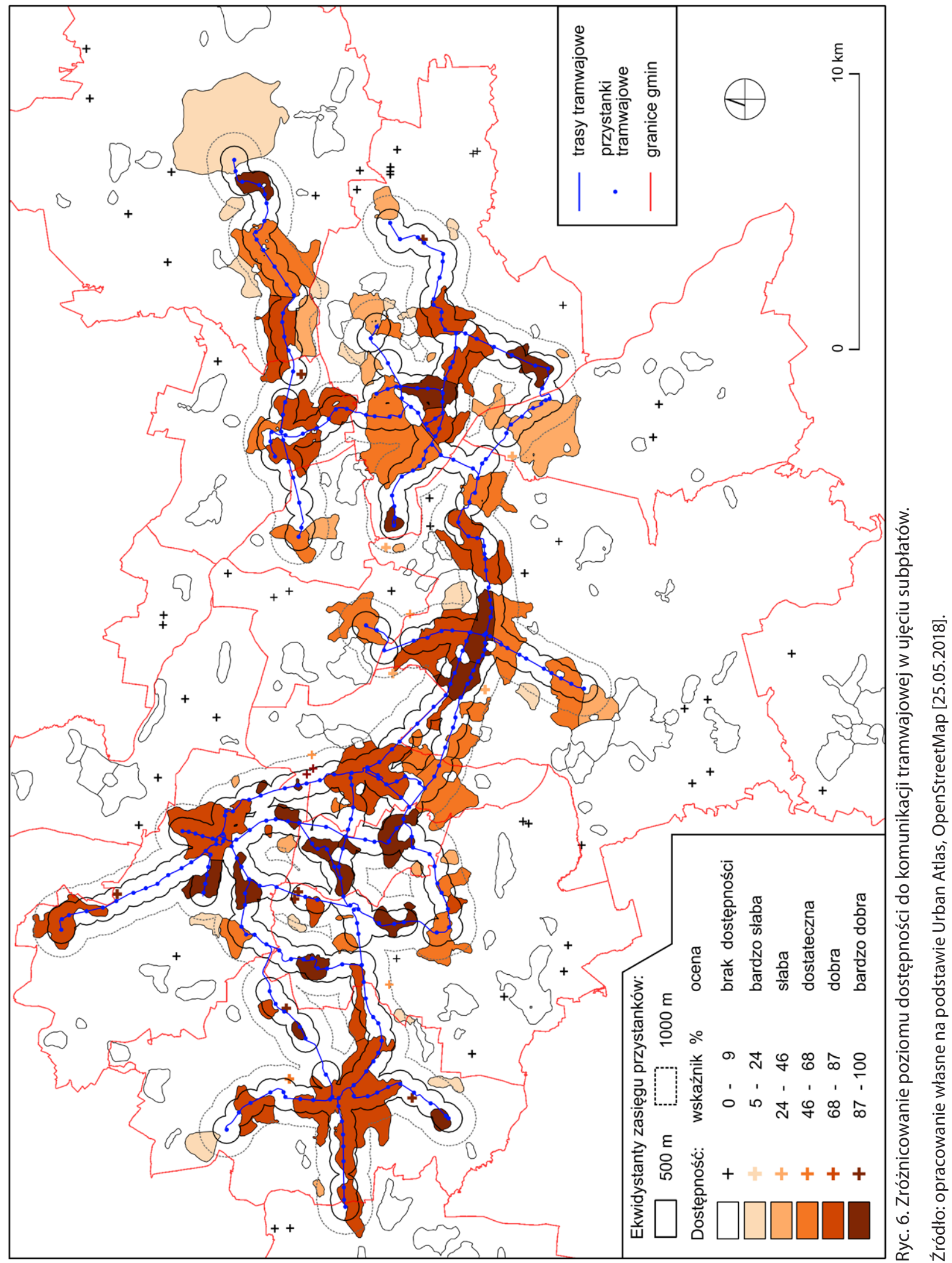


Bardzo duże i duże płaty wykazują zróżnicowanie pod względem poziomu dostępności składających się na nie subpłatów. Oznacza to, że w dużych, zwartych kompleksach o miejskim sposobie użytkowania dostępność do tramwaju jest nierównomierna. Najmniej zróżnicowane są największe płaty Zabrza i Bytomia. Bardzo niekorzystne jest zróżnicowanie poziomu dostępności takie, jak w płacie na terenie Sosnowca obejmującym Zagórze i Klimontów. Z jednej strony tramwaj dociera do tego płata, a z drugiej najbardziej potrzebujące obsługi tym środkiem transportu wielkie osiedla mieszkaniowe znajdują się w subpłatach o słabej lub z brakiem do niego dostępności.

Z obsługi komunikacją tramwajową całkowicie wykluczone zostały trzy płaty bardzo duże i jeden duży. Wszystkie zawierają subpłaty o strukturze miejskiej, w tym śródmieścia. W przypadku płata w Gliwicach jest to wysoce niekorzystne. Leży on blisko innego bardzo dużego płata w Zabrzu i wcześniej miał z nim połączenie tramwajowe. Do wykluczonych płatów bardzo dużych zalicza się płat na południu Katowic. Tylko dwa z siedmiu jego subpłatów mają dostęp do tramwaju, ale nawet $w$ nich dostępność jest słaba. Za negatywny nie można uznać faktu braku obsługi przez tramwaj płata w Tychach. Istnieje tam sieć trolejbusowa będąca substytutem komunikacji tramwajowej. Ze względu na wyraźne oddalenie od pozostałych większych płatów jego integrację z pozostałymi miastami powinna zapewnić kolej. Spośród płatów dużych wykluczony został tylko płat w Piekarach Śląskich.

Do najważniejszych obszarów reprezentowanych przez płaty bardzo małe i małe wykluczonych z dostępu do tramwaju należą osiedle w bytomskich Miechowicach, osiedle Giszowiec w Katowicach - wraz z kopalnią "Staszic", osiedle Brzęczkowice w Mysłowicach, siemianowickie Michałkowice, Bielszowice, Kochłowice i Halemba w Rudzie Śląskiej, płaty reprezentujące gliwicką Sośnicę.

Z 15 płatów zawierających w sobie subpłaty utożsamiane z centrami 16 miast (Chorzów i Świętochłowice objęte są jednym płatem) w zasięgu sieci tramwajowej znalazło się 10. Sieć tramwajowa nie objęła zasięgiem bardzo dużych płatów zawierających śródmieścia w Gliwicach i Tychach oraz dużego w Piekarach Śląskich, a także bardzo małego obejmującego centrum gminy Wojkowice.

\section{Układ linii komunikacyjnych}

W modelu oferty przewozowej komunikacji tramwajowej uwzględniono 24 linie (ryc. 7). W rozkładach jazdy tramwajów stosowane są następujące moduły częstotliwości kursowania: 10, 15, 20 i 30 min. Jedynie linia 26 kursuje w takcie 12-minutowym. Po- szczególne moduły częstotliwości dobierane są pod kątem ograniczeń technicznych stwarzanych przez infrastrukturę, potrzeb przewozowych, a także decyzji politycznych o ograniczeniu poziomu oferty przewozowej. Próba ujęcia przestrzennych prawideł w rozmieszczeniu linii o danym module częstotliwości nie zakończyła się powodzeniem. Większość linii w Zagłębiu kursuje co 20 min, z wyjątkiem linii 26 co 12 min, i jadącej na Śląsk linii 15 - co 15 min. Linie w śląskiej części sieci kursują przeważnie co 15 min, ewentualnie co $30 \mathrm{~min}$. Jednak w śląskich podsystemach "Zabrze”, „Bytom" i „Ch-Św-RŚl” występują także linie z modułem 20-minutowym. Linie tramwajowe, z nielicznymi wyjątkami, głównie w weekendy, przez cały dzień kursują z jedną, ustaloną dla danej linii częstotliwością przez cały dzień, tj. od ok. 5:00 do ok. 18:00-20:00 (zależnie od linii) po czym następuje zmniejszenie częstotliwości o połowę i ograniczenie komunikacji tramwajowej w godzinach nocnych.

Układ linii nawiązuje do podziału sieci na podsystemy. Nie istnieje żadna linia komunikacyjna pod względem topologicznym dłuższa, niż maksymalna liczba asocjacji wierzchołka. Najdłuższe linie przebiegają maksymalnie przez trzy podsieci (wg podziału na podsieci najmniejsze). Wynika z tego brak wielu bezpośrednich połączeń pomiędzy oddalonymi węzłami przesiadkowymi i bardziej oddalonymi od siebie miastami, np. Zabrze-Katowice, SosnowiecChorzów.

Na pierwszym poziomie podziału - „Śląsk" i "Zagłębie" - tylko jedna linia przejeżdża do podsystemu sąsiedniego. Jest to linia relacji centrum Katowic-centrum Sosnowca-Zagórze. Druga z linii dojeżdżających na stronę śląską dociera tylko do pętli będącej granicą między podsystemami i nie penetruje głębiej podsystemu śląskiego. Aż sześć linii pięcioma trasami przejeżdża z podsieci „Zabrze-Bytom” do podsieci "Kat-Ch-Św-RŚl". Wszystkie one przejeżdżają przez wydzieloną w jej obrębie podsieć "Ch-Św-RŚl", a tylko trzy docierają do podsieci "Katowice”. Występują linie w całości funkcjonujące w obrębie tylko jednego z tych podsystemów - cztery w podsystemie "Zabrze -Bytom" oraz trzy w podsystemie "Kat-Ch-Św-RŚl”. Także w obrębie najmniejszych podsieci funkcjonują linie wewnętrzne. Spośród 24 linii aż 12 kursuje w obrębie jednej tylko podsieci, dziewięć łączy dwie sąsiadujące podsieci, a tylko trzy biegną przez trzy podsieci. W obrębie wyłącznie podsieci „Zabrze” kursują - dwie z pięciu linii, „Bytom” - jedna z siedmiu, "Katowice" - pięć z dziewięciu, "Sosnowiec" - dwie z pięciu, "Będzin” - dwie z czterech. Wszystkie trzy linie łączące więcej niż dwie podsieci koncentrują się w śląskiej części sieci pomiędzy podsieciami „Katowice", , Ch-Św-RŚl” i „Bytom”. To połączenie zapewnione jest na dwóch ciągach komunikacyjnych przez trzy 
linie - przez centrum Chorzowa (linie 6i 19) oraz przez Świętochłowice (linia 7). Wszystkie te linie posiadają dobrą 15-minutową częstotliwość kursów.

W podziale na najmniejsze podsieci ("Zabrze”, "Bytom”, "Ch-Św-RŚl”, "Katowice”, "Sosnowiec”, „Będzin") przez każdy z tych podsystemów można przejechać linią o charakterze średnicowej zarówno w kierunku N-S, jak i W-E. Wyjątek stanowi podsieć "Ch-Św-RŚl", całkowicie nieprzejezdna bez przesiadki w Chebziu w relacji W-E. Podsieć ta jest ponadto zdecydowanie lepiej zintegrowana poprzez bezpośrednie, liczniejsze i częściej kursujące linie z siecią katowicką i bytomską niż zabrzańską.

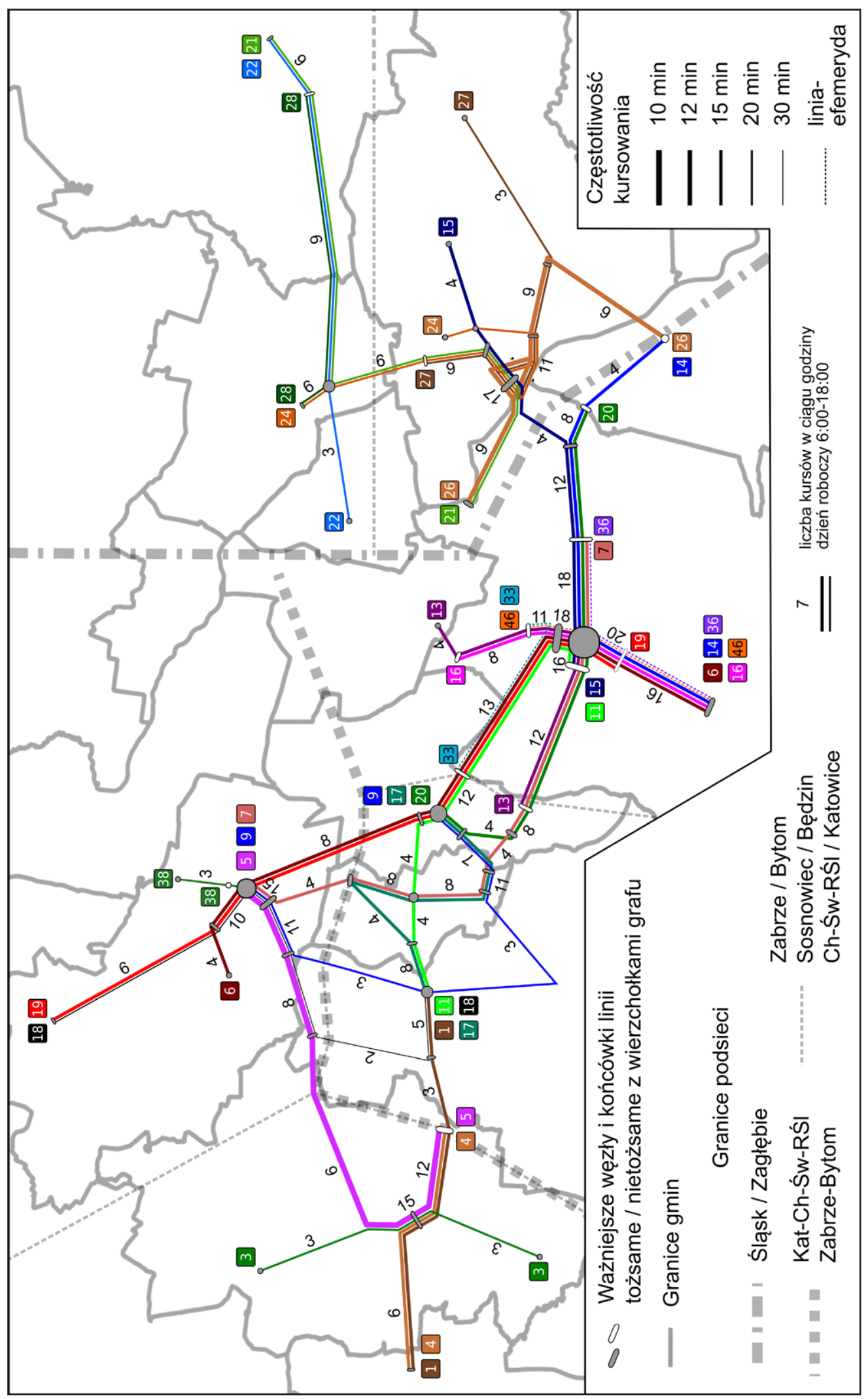


Nie wszystkie linie docierają do najbardziej centralnego punktu całej sieci, tj. katowickiego Rynku (wierzchołek nr 25). Niemniej każda linia przejeżdża przez przynajmniej jeden wierzchołek uznany w wybranej podsieci za najlepiej dostępny. Nie ma linii o charakterze obwodowym, pomijającej najbardziej centralne punkty sieci. Linie tramwajowe obsługują przede wszystkim lokalne centra, w niektórych przypadkach łącząc centra sąsiadujące ze sobą.

Najbardziej obciążone ruchem punkty leżą w obrębie największych płatów - dużych i bardzo dużych. Wyjątkiem jest Chebzie - miejsce kończenia biegu wielu linii. Miejsce to, pretendujące do stanowienia jednego z ważniejszych węzłów przesiadkowych, położone jest poza jakimkolwiek płatem.

Jedna linia komunikacyjna łączy najwyżej trzy płaty bardzo duże. Liniami takimi są 6 i 21. Linia 6 łączy bardzo duże płaty z terenu Katowic i Chorzowa oraz duży płat w Bytomiu. Linia 21 kursuje w Zagłębiu i łączy bardzo duży płat Sosnowca, przez duży w Będzinie z dwoma dużymi w Dąbrowie Górniczej.

Najbogatsza oferta w połączeniach między płatami występuje pomiędzy Katowicami (szczególnie ich północnym bardzo dużym płatem) a bardzo dużym płatem w Chorzowie. Linie je łączące dobrze penetrują oba płaty docierając do wszystkich ich subpłatów. Przez bardzo duży płat w Chorzowie przejeżdżają też trzy linie łączące duży płat Bytomia z płatami w Katowicach. Silne, choć oparte na jednej tylko trasie, ale obsługiwanej wiązką linii z wysoką łączną częstotliwością, są powiązania dużego płata w Będzinie i bardzo dużego w Dąbrowie Górniczej.

Linie zbiegają się w szersze niż liczące dwie linie wiązki w najlepiej dostępnych wierzchołkach, ewentualnie ich sąsiadach, całej sieci lub poszczególnych podsieci. Dotyczy to także wierzchołka nr 18 - centralnego dla podsieci "Ch-Św-RŚl” - wprawdzie nie powstaje tu żadna nowa wiązka, ale podwójna wiązka krzyżuje się z poprzeczną pojedynczą linią. Najszersze wiązki - do sześciu linii, i największa liczba linii - 10, przejeżdża przez najlepiej dostępny z całej sieci wierzchołek Katowice Rynek (nr 25).

Szerokość wiązek linii spada w miarę oddalania się od wierzchołków centralnych i największych płatów zawierających śródmieścia miast. Dotyczy to zarówno całej sieci, jak i podsieci. Oznacza to, że linie zbiegają się do lokalnych punktów centralnych sieci położonych w lokalnych centrach konurbacji. Punkty te obsługują dużą liczbę kierunków. Podsieci leżące peryferyjnie mają uboższą ofertę przewozową, niż podsieć "Katowice".

Liczne odcinki tras obsługiwane są przez pojedyncze linie. Są to linie o wysokich, jak i bardzo niskich częstotliwościach kursowania - co 10 i 12 min, ale też zaledwie co 20 i $30 \mathrm{~min}$. Strefą dominacji tego typu rzadko obsługiwanych odcinków jest zachodnia część podsieci "Ch-Św-RŚI”. Mało atrakcyjną częstotliwość poza wymienioną podsiecią oferują: $w$ Zabrzu połączenie północ-południe (20 min), w Bytomiu linia 38 (20 min), w Zagłębiu do Kazimierza Górniczego, Konstantynowa i Czeladzi (20 min). Obsługa pojedynczą linią co 15 min występuje też w połączeniach Katowice-Mysłowice i do Siemianowic Śląskich.

\section{Podsumowanie i dyskusja}

Sieć tramwajowa konurbacji katowickiej obsługuje specyficzny, policentryczny obszar. Jest wyraźnie zróżnicowana przestrzennie. Można w niej wydzielić kilka mniejszych podsieci. Zróżnicowanie przestrzenne pomiędzy nimi dotyczy kształtu sieci, charakteru infrastruktury, dostępności do komunikacji tramwajowej, a także znaczenia sieci dla przewozów lokalnych lub metropolitalnych. Zróżnicowany wpływ możliwości przejazdu tramwajem na integrację pomiędzy miastami wynika ze zróżnicowanego stopnia dopasowania rozmieszczenia infrastruktury tramwajowej i oferty przewozowej do układu przestrzennego konurbacji. Na wykształcenie się obecnego kształtu sieci i jej roli wpływ miały czynniki historyczne. Tym samym potwierdzona została postawiona na wstępie hipoteza.

Najbardziej zaznacza się podział na sieć śląską i zagłębiowską, nawiązujący do granicy pruskorosyjskiej. Mniej wyraźnie zaznaczyła się granica polsko-niemiecka z okresu międzywojennego, choć uwzględniając jej przebieg można wyróżnić wyraźnie dwubiegunowy podsystem tramwajowy Bytomia i Zabrza.

Sieć konurbacji katowickiej jest bardzo zróżnicowana przestrzennie pod względem kształtu. W poszczególnych podsieciach odnaleźć można cechy układu kratowego, trójkątnego i rdzeniowego.

Centralnym punktem sieci, zarówno pod względem dostępności topologicznej, jak i liczby oferowanych kierunków podróży i powiązań z sąsiednimi płatami jest katowicki Rynek. Występują wyraźne lokalne punkty centralne w podsieciach.

Omawiana sieć tramwajowa w układzie podsieci jest zróżnicowana pod względem infrastruktury. Ponad 1/3 ogółu torowisk to odcinki jednotorowe. Ogranicza to możliwość kształtowania atrakcyjnej oferty przewozowej. Szczególnie niekorzystne jest ich nagromadzenie w podsieci "Ch-Św-RŚl”. Leży ona w środkowej części podsieci "Śląsk", przez co utrudnione jest prowadzenie linii tranzytowych, np. z Zabrza w kierunku Chorzowa dla utworzenia połączenia o randze metropolitalnej.

Każda z wydzielonych podsieci uzyskała predyspozycje do zaspokajania przede wszystkim lokalnych 
potrzeb przewozowych. Mimo to istnieje grupa podsieci o dużym znaczeniu dla integracji kilku obszarów konurbacji na poziomie ponadlokalnym (ryc. 8). W sieci tramwajowej konurbacji katowickiej można zatem wskazać podsieci dwóch rodzajów:

I. zorientowane głównie na dojazdy lokalne,

II. o charakterze metropolitalnym, integrujące kilka intensywnie zurbanizowanych obszarów. dowy. Z tego powodu zachodnią część tej podsieci należy traktować jak podsieć typu I. Podsieć "Zabrze” jest typowym przykładem podsieci I rodzaju. Ma tylko jedno zadowalające połączenie do innej podsieci i płata dużego. Choć dzięki silnej integracji z podsieciami "Ch-Św-RŚl” i „Katowice" podsieć "Bytom" należy do grupy II, nabiera ona też rodzaju I - duże znaczenie $w$ dowozach do centrum tego miasta przez
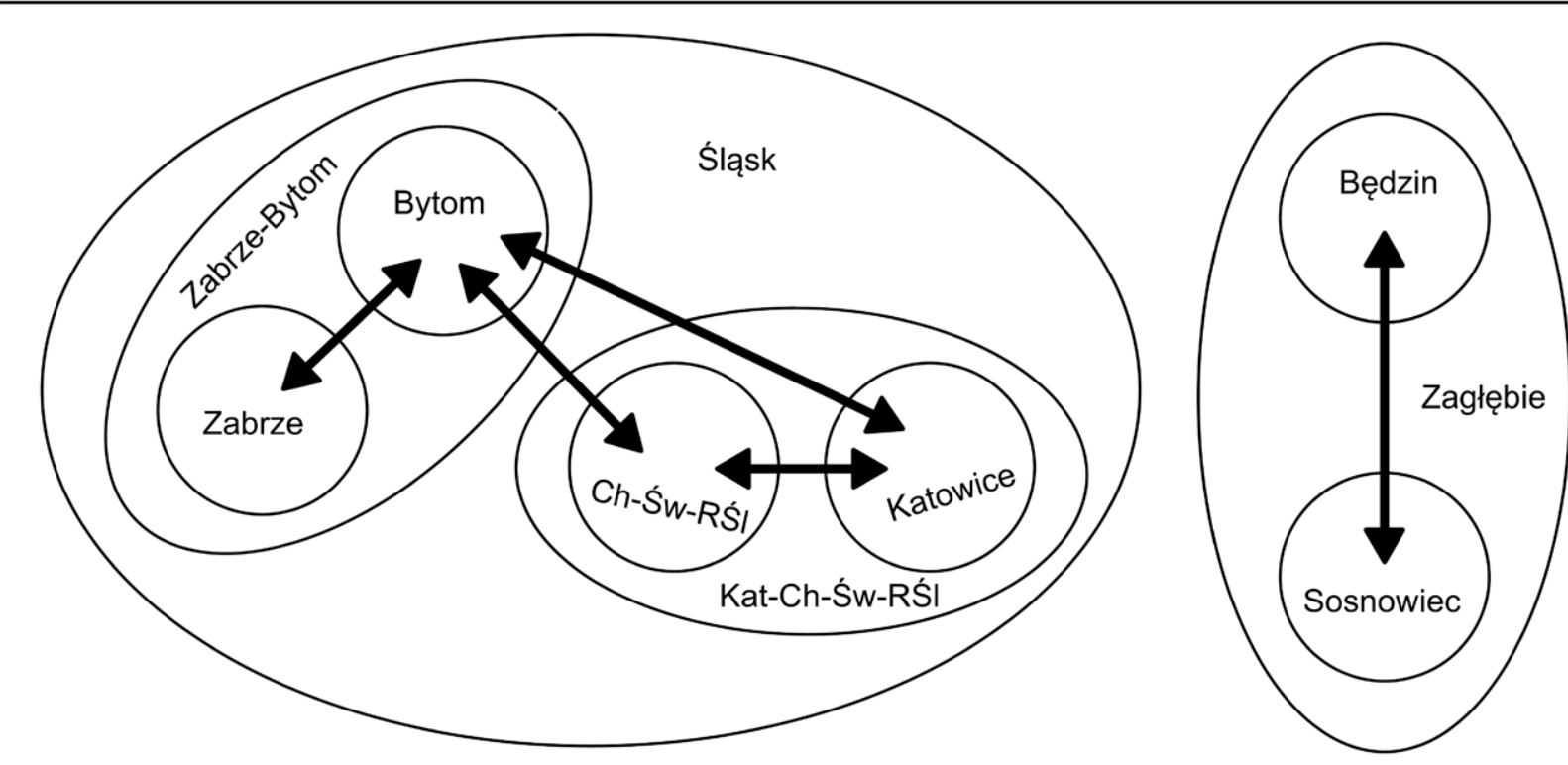

Ryc. 8. Główne powiązania pomiędzy podsieciami sieci tramwajowej konurbacji katowickiej.

Źródło: opracowanie własne.

Podsieci I rodzaju obsługują przede wszystkim podróże w obrębie dużych płatów i otaczających je płatów mniejszych. Sieci takie pod względem topologicznym przeważnie są drzewami z jednym wierzchołkiem centralnym wysokiego stopnia. Punkt ten leży najczęściej w środku dużego lub bardzo dużego płata zawierającego śródmieście. Do tego punktu gwiaździście zbiegają się trasy z okolicy. Mogą też mieć układ kratowy i realizować skomplikowane relacje pomiędzy bliskimi małymi płatami, jak w podsieci "Ch-Św-RŚl".

Podsieci II rodzaju zapewniają dojazd pomiędzy płatami z grupy bardzo dużych i dużych. Łączą ze sobą śródmieścia kilku miast. Jednocześnie zachowują istotną rolę w przewozach lokalnych w obrębie jednego miasta, płata. Podsieci takie cechuje duża liczba linii skierowanych kilkoma trasami do podsieci sąsiednich. Linie te tworzą wiązki o bardzo wysokiej (atrakcyjnej) częstotliwości kursów. Obejmują one pas łączący Bytom przez Chorzów i/lub Świętochłowice $z$ katowickimi płatami obejmującymi śródmieście oraz Zawodzie i Brynów.
W podziale na dwie duże podsieci - „Śląsk" i „Zagłębie"- obie należą do rodzaju I. Funkcjonują praktycznie niezależnie. Po względem topologicznym istnieje jedna tylko krawędź, której usunięcie spowoduje rozpad sieci na dwie oddzielne części. Tylko jedna linia tramwajowa, choć o dobrej 15-minutowej częstotliwości, daje realne połączenie pomiędzy oboma podsieciami. Drugie z połączeń śląsko-zagłębiowskich ogranicza się jedynie do dojazdu z obu stron do końcówki (pętli) zlokalizowanej tuż przy granicy obu regionów.

Dwóm podsieciom w Zagłębiu najbliżej do rodzaju I. Wprawdzie mają one relatywnie dobre połączenie pomiędzy sobą, jednak połączenie w obrębie każdej z nich stoi na znacznie wyższym poziomie.

W podsieci "Śląsk" występują małe podsieci zarówno rodzaju I, jak i II. Podsieci "Katowice”, "ChŚw-RŚl” i "Bytom" są podsieciami rodzaju II. Wyjątek stanowi zachodnia część podsieci "Ch-Św-RŚl” - dobrze zintegrowana infrastrukturalnie, ale słabo funkcjonalnie (brak linii komunikacyjnych), ponadto łącząca luźno rozrzucone mniejsze skupiska zabu- 
obsługę płata dużego z okolicznymi mniejszymi. Także sama podsieć „Katowice” wykazuje cechy rodzaju I - wszystkie linie zbiegają się do środka płata bardzo dużego zapewniając dowóz do śródmieścia.

Poszczególne części sieci dzięki rozmieszczeniu pętli mogą funkcjonować jako samodzielne niewielkie sieci. Niektóre podsieci cechuje znaczna autonomia od pozostałej części. Taki stan rzeczy z jednej strony jest wadą sieci konurbacji katowickiej jako całości, ponieważ nie jest ona wykorzystana należycie w integracji pomiędzy miastami. Z drugiej strony może to być zaleta - relatywnie dobrze odpowiada na potrzeby konkretnych części konurbacji. Niestety, bywa wykorzystywane do wprowadzania ograniczeń oferty przewozowej w przypadku różnic zdań co do finansowania komunikacji pomiędzy sąsiadującymi miastami - skracanie linii tylko do granicy miast, co zwiększa izolację poszczególnych podsieci.

Sieć traci na znaczeniu ze względu na zbyt słabe jej wykorzystanie w integracji pomiędzy miastami. W niektórych z podsieci oferowane połączenia międzymiastowe stanowią zaledwie ułamek ogółu. Tym samym odpada jedna z możliwych do pełnienia funkcji - przejazdy i integracja między większą liczbą istotnych płatów i miast. Pozostaje jedynie rola w przewozach lokalnych.

Drugą przyczyną zmniejszonej roli komunikacji tramwajowej jest brak obsługi istotnych generatorów ruchu. Ich pomijanie ogranicza znaczenie sieci dla podróży lokalnych, a co za tym idzie także metropolitalnych. Tramwaje często obsługują obszary słabo zaludnione, a jednocześnie poza zasięgiem ich przystanków pozostają istotne skupiska terenów zainwestowanych i ważne generatory ruchu.

Spośród występujących w literaturze podziałów sieci jedynie podział na trzy podsystemy daje właściwy jej obraz. Uwzględnia wszystkie zmiany geopolityczne na badanym obszarze i zdecydowanie najlepiej obrazuje istniejące w sieci problemy. Przeprowadzone badania wykazały jednak, że dopiero podział na jeszcze mniejsze podsieci pozwala w pełni zrozumieć sposób funkcjonowania badanej sieci tramwajowej.

Wprawdzie w publikacjach dotyczących sieci tramwajowej konurbacji katowickiej rozróżniano w jej obrębie kilka mniejszych podsystemów, lecz próby określenia jej roli podejmowane były przy ujmowaniu jej jako jednej zwartej całości. Przytoczone z literatury zdania dotyczące znaczenia komunikacji tramwajowej w konurbacji katowickiej - o utraconej szansie utworzenia tramwajów międzymiastowych (Kołoś, 2006) i istotnej roli w połączeniach między miastami (Halor, 2012), choć pozornie sprzeczne, są prawdziwe, ale wymagają uzupełnienia o aspekt zróżnicowania przestrzennego przedstawiony powy- żej. Spostrzeżenie A. Soczówki (2012c) o wydatnym wpływie połączeń tramwajowych na ogólną liczbę połączeń międzygminnych także można uzupełnić o stwierdzenie przestrzennego zróżnicowania tego wpływu. Teza S. Dziadka (1995) o ważnej roli tramwajów w integracji przestrzeni konurbacji katowickiej, znajduje potwierdzenie tylko dla wybranych części sieci. J. Petryszyn (1996) wskazuje na znaczenie tramwajów w integracji Śląska z Zagłębiem, ale czyni to w kontekście niewielkiej liczby innych połączeń (drogowych, kolejowych). Samych połączeń tramwajowych - tras, linii i kursów - jest jednak w tej relacji zbyt mało. W ujęciu topologicznym rozmieszczenie centralnych miejsc w sieci jest odmienne, niż opisane przez S. Dziadka (1995) na podstawie ruchu tramwajów. Choć zdaniem A. Soczówki (2012b) w konurbacji katowickiej wykształcił się międzymiastowy charakter połączeń tramwajowych, to obecnie zadanie przewozów między miastami nie jest główną rolą tramwajów. Duże znaczenie mają przewozy lokalne. W kontekście braku wielu połączeń - zwłaszcza Ślask-Zagłębie - licznych odcinków jednotorowych przy wieloletnim braku działań na rzecz ich poprawy, trafne jest spostrzeżenie A. Kołosia (2006) o zmarnowaniu szansy stworzenia szybkich połączeń międzymiastowych realizowanych tramwajem. Rolę w połączeniach o charakterze metropolitalnym tramwaje pełnią tylko pomiędzy Katowicami, Chorzowem i Bytomiem, co z kolei potwierdza słuszność tez J. Halora (2006) i A. Soczówki (2012b, 2012c) o występowaniu istotnych połączeń międzymiastowych.

Realizacja projektu „Modernizacja infrastruktury tramwajowej i trolejbusowej w aglomeracji katowickiej" nie wpłynęła na dezaktualizację przedstawionych wniosków. Oznacza to, że nie wpłynęła na zmianę roli tramwajów w konurbacji. Projekt ten pozwolił natomiast wykonać minimum prac potrzebnych do zachowania funkcjonowania komunikacji tramwajowej w tym regionie. W jego wyniku zmniejszył się też udział odcinków jednotorowych - na dwutorowe przebudowano połączenie Szopienic z Sosnowcem oraz Łagiewnik z Bytomiem.

\section{Piśmiennictwo}

Beim M., Majewski B., 2008, Dostępność komunikacji publicznej w Poznaniu, Rozwój Regionalny i Polityka Regionalna, 3.

Diagnoza stanu systemu transportowego oraz plan rozwoju transportu zbiorowego w obszarze działania KZK GOP Synteza opracowania, 2007, Ernst\&Young, WarszawaKatowice.

Dziadek S., 1995, Rola komunikacji tramwajowej w obsłudze przewozów pasażerskich w aglomeracjach miejskich GOP [w: K. Dwucet, T. Szczypek (red.), Wybrane zagad- 
nienia geograficzne. Pamięci geografów Uniwersytetu Śląskiego Józefa Szaflarskiego i Piotra Modrzejowskiego, WNoZ UŚ, PTG Oddział Katowicki, Sosnowiec, s. 65-86.

Forman R.T.T., Godron M., 1995, Land Mosaics. The ecology of landscapes and regions, University Press, Cambridge.

Gadziński J., 2010, Ocena dostępności komunikacyjnej przestrzeni miejskiej na przykładzie Poznania, Rozwój Regionalny i Polityka Regionalna, 13, s. 9-104.

Halor J., 2012, Konkurencyjność komunikacji tramwajowej na przykładzie aglomeracji górnośląskiej, praca doktorska, maszynopis dostępny w Czytelni Multimedialnej Bibliotek Wydziałowych Uniwersytetu Ekonomicznego w Katowicach.

Jackiewicz J., Czech P., Barcik J., 2010, Praktyka kształtowania oferty transportowej dla komunikacji transportowej w aglomeracji śląskiej, Zeszyty Naukowe Politechniki Śląskiej, Transport, 69, s. 49-57.

Kołoś A., 2006, Rozwój przestrzenny a współczesne funkcjonowanie miejskiego transportu szynowego w Polsce, IGiGP UJ, Kraków.

Loose W., 2001, Flächennutzungsplan 2010 Freiburg Stellungnahme zu den verkehrlichen Auswirkungen, Öko-Institut e.V. Arbeitsfeld Verkehr, Freiburg.

Mapa Taktyczna WIG 1:100 000.

Molecki A., 2007, Jednotorowe linie tramwajowe - eksploatacyjne aspekty projektowania, Technika transportu szynowego, 12/2007, s. 59-63.

Niemiecka mapa Mestichblatt 1:50 000.

OpenStreetMap, www.openstreetmap.org [28.02.2012]

Operacyjny program modernizacji infrastruktury tramwajowej w aglomeracji śląskiej w latach 2007-2013, 2006, Tramwaje Śląskie S.A., "System” Katowickie Przedsiębiorstwo Inżynierskie, Katowice.

Petryszyn J., 1996, Integracja transportowa miast i gmin leżących w pobliżu dawnej granicy na rzece Brynicy [w:] J. Runge (red.), Problemy społeczne rozwoju regionalnego. Materiały konferencji naukowej, Wydział Nauk o Ziemi Uniwersytetu Śląskiego, Sosnowiec, s. 61-65.
Pietrzak M., 2010, Podstawy i zastosowania ekologii krajobrazu, Państwowa Wyższa Szkoła Zawodowa im. Jana Amosa Komeńskiego w Lesznie, Leszno.

Potrykowski M., Taylor Z., 1982, Geografia transportu: zarys problemów, modeli i metod badawczych, PWN, Warszawa.

Rechłowicz M., 2010, Zmiany dostępności zakładów przemysłowych Sosnowca komunikacją tramwajową w latach 1990-2010, Acta Geographica Silesiana, 8, s. 39-45.

Rychling A., Solon J., 2011, Ekologia krajobrazu, PWN, Warszawa

Runge J., 1992, Wybrane zagadnienia analizy przestrzennej wbadaniach geograficznych, Uniwersytet Śląski, Katowice.

Soczówka A., 2012a, Dostępność przestrzenna komunikacji miejskiej w konurbacji katowickiej, [w:] P. Rosik, W. Wiśniewski (red.), Dostępność i mobilność w przestrzeni, Wyd. IGiPZ PAN, Warszawa, s. 197-204.

Soczówka A., 2012b, Zarys historii komunikacji tramwajowej na obszarze konurbacji katowickiej, Acta Geographica Silesiana, 11, s. 57-69.

Soczówka A., 2012c, Zróżnicowanie struktury przestrzennej komunikacji miejskiej w konurbacji katowickiej, Prace Wydziału Nauk o Ziemi Uniwersytetu Śląskiego, 76, Uniwersytet Śląski, Wydział Nauk o Ziemi, Sosnowiec.

Soida K., 1998, Komunikacja tramwajowa waglomeracji katowickiej, Przedsiębiorstwo Komunikacji Tramwajowej w Katowicach i Wydawnictwo "Stapis", Katowice.

Soida K., Danyluk Z., Nadolski P., 2010, Tramwaje górnośląskie, t. I, t. II, Eurosprinter, Rybnik.

Urban Atlas 2006, Copernicus, https://land.copernicus.eu/ local/urban-atlas/urban-atlas-2006?tab=download [28.11.2012]

Wilczek J., b.d., Rozwój sieci tramwajowej Górnośląskiego Okręgu Przemysłowego, http://wilczekkk.republika.pl/ schem/schem.htm [28.02.2012]

Wilson R.J., 1985, Wprowadzenie do teorii grafów, PWN, Warszawa. 